\title{
Okul Öncesi Öğretmenlerinin Kaynaştırma Ĕgitimine Ve "Okul Öncesi Eğitimde Kaynaştırma Eğitimi Hizmet İçi Eğitim Programı"na İlişkin Görüşleri
}

\author{
Yrd. Doç. Dr. Latife Özaydın* \\ Gazi Üniversitesi, Ankara Meslek Yüksek Okulu, \\ Emniyet Mah. Muammer Yaşar Bostancı Cad. No:5, 06500 Beşevler / Ankara / Türkiye \\ Yrd. Doç. Dr. Aysun Çolak \\ Anadolu Üniversitesi, Eğitim Fakültesi, \\ Özel Eğitim Bölümü Yunus Emre Kampüsü, 26470 Eskişehir / Türkiye
}

\section{Özet}

1997 yılında yayımlanan 573 sayılı Özel Eğitim Hakkında Kanun Hükmünde Kararname ve 2006 yılında yayımlanan Özel Eğitim Hizmetleri Yönetmeliği’nde özel gereksinimli çocukların okulöncesi eğitimlerinin zorunlu hâle getirilmesi ile bu çocukların söz konusu kurumlara yerleştirilmeleri, özel eğitim ve kaynaştırma konusunda yeterli donanıma sahip olmayan okulöncesi öğretmenlerinin karşılaştıkları sorunları artırmıştır. Dolayısıyla yaşanan zorluklar, okul öncesi öğretmenlerinin kaynaştırma eğitimine olan tutumlarını olumsuz etkilediği, özel gereksinimli çocukların ve normal gelişim gösteren çocukların kaynaştırma eğitiminden faydalanamadıklarını göstermiştir. $\mathrm{Bu}$ doğrultuda bu çalışma ile, “Okul Öncesi Eğitimde Kaynaştırma

* Sorumlu Yazar. Tel:+90 3122126768 - 203 E-posta: lozaydin@gazi.edu.tr

(C) 2011 Kalem Eğitim ve Sağlık Hizmetleri A.Ş. Bütün Hakları Saklıdır ISSN: 2146 - 5606 
Eğitimi” hizmet içi eğitim etkinliğine katılan ve en az bir eğitim öğretim yılı sınıfina özel gereksinimli bir çocuğun yerleştirilmesi ile kaynaştırma deneyimi yaşayan okul öncesi öğretmenlerinin; a) kaynaştırma eğitimine ve b) katıldıkları "Okul Öncesi Eğitimde Kaynaştırma Eğitimi” hizmet içi eğitim programına ilişkin görüşleri belirlenmiştir. Araştırmanın katılımcılarını, okul öncesi eğitimde kaynaştırma eğitimi hizmet içi programına katılan dokuz okul öncesi öğretmeni oluşturmuştur. Nitel verilere dayalı bir durum çalışması olan bu araştırmada, ihtiyaç duyulan veriler araştırmacılar tarafindan geliştirilen ve 13 soruyu kapsayan bir görüşme formu kullanılarak toplanmıştır. Araştırma sonucunda okul öncesi eğitimi öğretmenlerinin, Kaynaştırma Eğitimi Hizmet İ̧̧i Eğitim Programlarının uygulamada yaşadıkları sorunlara yönelik olarak düzenlenmesine ve yanı sıra özel eğitim danışmanlı̆ğ, sınıfta yardımcı bir ögretmen ve kaynak oda desteğine ihtiyaç duydukları tespit edilmiştir.

Anahtar kelimeler: Kaynaştırma eğitimi; Okul öncesi öğretmeni; Okul öncesi eğitimde kaynaştırma; Hizmet içi eğitim programı.

\title{
The Views of Preschool Education Teachers over Mainstreaming Education and over In-service Education Program of Mainstreaming Education at Preschool Education
}

\begin{abstract}
In the legislative decree over Special Education with a number of 573 enacted in 1997 and in the "Regulation of Special Education Services" enacted in 2006, registering the children with special needs into the mentioned increased the problems the preschool teachers with no adequate experience had over special education and mainstreaming with making the preschool education compulsory for these children. Therefore, the challenges in this issue showed that these problems had a reverse effect on the behaviours of preschool education and that children with special needs and those with a normal development were not able to benefit from mainstreaming education. In this sense, the current study aimed at determining the views of preschool teachers par-
\end{abstract}


ticipating in the educational activity of "Mainstreaming Education at Preschool Education" and having experience with a child of special need registered into his/her class at least one year over; a) mainstreaming education and b)in-service training program of "Mainstreaming Education at Preschool Education". The participants of the current study are made up of nine preschool teachers included in the in service training of preschool mainstreaming education. In current study, which is a qualitative case research, the data needed were gathered through an interview form developed by the researchers including 13 items. In conclusion, it was found those preschool teachers pointed out that In-service Programs of Mainstreaming Education should be designed depending on the challenges they have had in the application and that they need special education consultancy, an assistant teacher and a resource room in the class.

Key words: Mainstreaming education; Preschool education teacher; Mainstreaming education at preschool education; In-service training program.

\section{Giriş}

Ülkemizde 1997 yılında yayımlanan 573 sayılı Özel Eğitim Hakkında Kanun Hükmünde Kararname (KHK) ve bu KHK hükümlerine dayanılarak hazırlanan Özel Eğitim Hizmetleri Yönetmeliği (ÖEHY)'nde (2006), özel gereksinimi olan çocukların okul öncesi eğitimleri zorunlu hâle getirilmiş ve son yönetmelikte, kaynaştırma eğitiminin uluslararası literatür ile paralel bir tanıma ulaştığı görülmektedir. ÖEHY'nde (2006), kaynaştırma yoluyla eğitimin; “Özel eğitime ihtiyacı olan bireylerin eğitimlerini, destek eğitim hizmetleri de sağlanarak yetersizliği olmayan akranları ile birlikte resmî ve özel; okul öncesi, ilköğretim, ortaöğretim ve yaygın eğitim kurumlarında sürdürmeleri esastna dayanan özel eğitim uygulamaları" olarak tanımlandığ 1 ve destek eğitim hizmetlerine vurgu yapıldığ1 dikkat çekmektedir. Söz konusu yönetmelikte Destek Eğitim Hizmetlerinin ise "Özel eğitime ihtiyacı 
olan bireylerin tıbbi ve eğitsel değerlendirme ve tanılama sonucunda belirlenen eğitim ihtiyaçları doğrultusunda kendilerine, ailelerine, öğretmenlerine ve okul personeline uzman personel, araç-gereç, eğitim ve danışmanlık hizmetleri sağlama" olarak tanımlandığı görülmektedir. ÖEHY'nin yanı sıra Okul Öncesi Eğitim Kurumları Yönetmeliği’nde (2009) "Rehberlik araştırma merkezlerinde oluşturulan Özel Ĕ̈itim Değerlendirme Kurulunca düzenlenen rapor sonucunda okul öncesi eğitim kurumlarına yerleştirilmeleri uygun görülen 36-72 aylık çocuklar, ă̆ır ve çok ă̆ır düzeyde zihinsel ve birden çok yetersizliği olmamak şartıyla 10 çocuk bulunan sinıflarda ikiden, 20 çocuk bulunan sınıflarda ise birden fazla olmayacak şekilde kaydedilirler." ibaresinin yer aldı̆̆ı görülmektedir.

Yapılan yasal düzenlemelerle ülkemizde, özel gereksinimli çocukların okul öncesi eğitimlerinin güvence altına alındığı görülmektedir. Ancak, okul öncesi eğitim kurumlarında kaynaştırma eğitimine katılan çocuk sayısı, özel gereksinim alanlarına göre kaynaştırma eğitimine katılım oranları, yarı ya da tam zamanlı olarak kaynaştırma eğitimine katılım biçimleri ve kaynaştırma eğitiminin izlenmesi ve değerlendirilmesine ilişkin nicel ve nitel verilere dayalı MEB kaynaklı ulusal bir raporun mevcut olmadığı görülmektedir. Bu eksikliğin alan araştırmacılarını, okul öncesi eğitimde kaynaştırma uygulamalarında yaşanan sorunlar ve çözüme yönelik çalışmalara yönlendirdiği görülmektedir. Okul öncesi eğitim kurumlarında kaynaştırma uygulamalarına ilişkin mevcut çalışmalara geçmeden önce, ülkemizde okul öncesi eğitimin durumu hakkında genel bir değerlendirme yapmanın gerekli olduğu düşünülmektedir.

Ülkemizde okul öncesi eğitimin MEB sisteminde ilk kez gündeme geldiği 1961 yılında yayımlanan 222 sayılı İlköğretim ve Eğitim Kanunu'nun yürürlüğe girmesinden günümüze kadar, okul önce- 
si kurumlarının; mecburi öğrenim çağına gelmemiş olan çocukların isteğe bağlı eğitimlerinin sürdürüldüğü kurumlar olarak tanımlanmasının, bu eğitim kurumlarının öneminin anlaşılması ve yaygınlaşmasını geciktirdiği düşünülmektedir. Ayrıca, zorunlu eğitim çağındaki çocukların eğitimlerinde, ulusal ve uluslararası göstergelere ulaşma gayretinin geçen y1llar içinde okul öncesi eğitimin göz ardı edilmesine zemin hazırlayan bir başka gerçek olduğu da düşünülmektedir. 1992 yılında kurulan Okul Öncesi Eğitimi Genel Müdürlüğünün, MEB bünyesinde oluşturulan son birkaç genel müdürlükten biri olması bunun bir göstergesidir. Ülkemizde, son yıllarda genel bütçeden en büyük payın eğitime ayrıldığı bilinmesine rağmen, MEB genel bütçesi içinde Okul Öncesi Eğitimi Genel Müdürlüğüne ayrılan payın \% 1'i geçmediği görülmektedir. Bu doğrultuda, genel müdürlüğün kurulduğu 1992-1993 öğretim y1lında okul öncesi eğitimde \% 5.2 olan okullaşma oranının, 2009-2010 öğretim yılı istatistiklerinde ancak \% 43'e yükseltilebildiği görülmektedir (MEB, 2010-2011). Türkiye'nin okul öncesi eğitimde okullaşma oranlarının uluslararası göstergelerin gerisinde oluşunu (NonoyamaTarumi, Y ve Ota, Y. 2011; TÜSİAD, 2005), MEB'in sınıf ortamlarında daha az personel ile daha çok çocuğun istihdamı sağlanarak okullaşma oranlarını arttırma girişimleri ile çözümleme yoluna gittiği bilinmektedir. Ancak, bu uygulamanın sonucu sınıflardaki çocuk sayısının artışına bağlı olarak fiziksel mekân, materyal yetersizliği ve sınıf içi problem davranışların sıklığının okul öncesi öğretmenlerinin sorunlar karşısında çaresizlik yaşadığını göstermektedir. Okul öncesi eğitimde yaşanan bu zorlu tabloya, kaynaştırma uygulamaları gereği özel gereksinimli çocukların yerleştirilmesi, özel eğitim ve kaynaştırma konusunda yeterli donanıma sahip olmayan okul öncesi öğretmenlerinin karşılaştıkları sorunları daha da arttırdığı bilinmektedir (Altun ve Gülben, 2009; Gök ve Erbaş, 2011; Temel, 2000).

$\mathrm{Bu}$ bağlamda okul öncesi eğitimde kaynaştırma uygulamalar1- 
nın başarıya ulaşabilmesi için, öğretmenler, normal gelişim gösteren çocuklar, kaynaştırma öğrencileri, her iki grup çocuğun aileleri, okul yönetimi, destek özel eğitim hizmetleri ve ek hizmetlerin (Batu ve Kırcaali-İftar, 2006) kaynaştırma eğitimi uygulayan sınıflarda dikkate alınması ve öğretmene gerekli desteğin verilmesi gerekmektedir. Destek özel eğitim hizmetlerinin Sucuoğlu ve Kargın (2006) tarafindan, sınıf içinde (danışman, özel eğitim öğretmeni ve iş birlikçi öğretim destekli) ve sınıf dışında (kaynak oda ve gezici özel eğitim öğretmeni) sunulan destek eğitim hizmetleri olarak sınıflandırıldığı görülmektedir. Batu ve Kırcaali-İftar (2006) ise özel eğitim destek hizmetlerinin; kaynak oda eğitimi, sınıfiçi yardım ve özel eğitim danışmanlığı şeklinde sunulabileceğini belirtmişlerdir. Türkiye'de Kaynaştırma/Bütünleştirme Yoluyla Eğitimin Durumu (2011) raporunda, kaynaştırma eğitiminde yaşanan sorunların temelinde, kaynaştırma eğitiminin ayrılmaz bir parçası olan destek eğitim hizmetlerinin yetersizliğinin vurgulandığı, mevzuatta yer alan gelişmelerin uygulamaya yansıtılmasında sorunlar yaşandığına dikkat çekilmiştir. Sınıf öğretmenlerinin, sınıflarına gelecek özel gereksinimli çocuklar konusunda bilgilendirilmeleri, etkili bir sınıf yönetimi uygulayabilmek için, problem davranışların azaltılması, olumlu davranışların arttırılması konusunda destek özel eğitim hizmetlerinin sağlanması gerekliliği vurgulanmıştır. Ülkemizde okul öncesi eğitimde kaynaştırma eğitimi uygulamaları hakkındaki yasal mevzuatta ve ulusal kaynaklarda kaynaştırma eğitimi uygulamalarında destek hizmetlerinin neler olması gerektiği ve yaşanan sorunlara ilişkin genel bir açıklamaya yer verilmiştir. İzleyen bölümde, uluslararası alan yazında, okul öncesi eğitimde kaynaştırma eğitimi uygulamaları konulu araştırmalara yer verilmiştir.

Odom, McConnell ve Chandler (1994), okul öncesi eğitimi öğretmenlerinin yetersizliği olan çocuklarla uygulama yapabilme konusundaki algılarının, uygulama için gereken zaman, bilgi düzeyleri, 
kaynaklara ulaşım, fiziksel mekân ve normal gelişim gösteren akranların yetersizliği olan çocuğu kabul düzeyleri gibi pek çok farklı değişkenden etkilenebildiğini belirtmişlerdir. Odom (2000), okul öncesi eğitim kurumlarına yerleştirilen ve sayıları giderek artan yetersizliği olan çocukların eğitim ortamından yararlanabilmeleri için okul öncesi eğitimi öğretmenlerinin müdahale programlarını uygulayabilme konusunda eğitime gereksinimleri olduğunu belirtmiştir. Rheams ve Bain (2005)'in özel eğitim okul öncesi eğitim sınıfı ve kaynaştırma okul öncesi eğitimi sınıfı öğretmenlerinin, kaynaştırma eğitimi ve sosyal etkileşim müdahalelerini uygulayabilmeleri hakkındaki algılarının incelendiği çalışmada, eğitim geçmişleri farklı olan bu iki grup öğretmenin kaynaştırma eğitiminin gerekli olduğunu savundukları tespit edilmiştir. Farklılığın ise sosyal etkileşim müdahale programını kullanma konusunda olduğu görülmüştür. Özel eğitim okul öncesi sınıf öğretmeninin sınıflarındaki çocukların tümünün yetersizliklerinden dolayı sosyal etkileşim açısından homojen bir yapıya sahip oldukları ve bu nedenle bu öğretmenlerin daha çok bireysel sosyal beceri öğretimi uyguladıkları tespit edilmiştir. Okul öncesi sınıf öğretmenlerinin ise sınıflarında en az bir yetersizliği olan çocuk olduğu için akranları ile sosyal etkileşimlerini desteklemek için müdahale programına daha sık gereksinim duydukları belirlenmiştir. Scott-Little, Kagan ve Frelow (2003)'un çalışmasının bulguları arasında, yetersizliği olan çocukların katıldığı okul öncesi eğitim sınıfı öğretmenlerinin, bu çocukları destekleyebilmek için erken öğrenme standartları konusunda danışmanlık hizmetlerine gereksinimleri olduğu, materyal, eğitim ve teknik yardım gibi konularda desteklenmeleri gerektiğine yer verilmiştir. Macy, Squiers ve Barton (2009), Erken Çocukluk (EÇ), Erken Müdahale (EM) ve Erken Çocukluk Özel Eğitimi (EÇÖE) alanlarında öğretmen yetiştiren programların, kuruluş ve felsefelerinin birbirinden farklılıklar göstermesine rağmen, günümüzde bu programlardaki öğretmen adaylarının uygulama yaptığı ve 
mezuniyet sonrası yerleştiği sınıflardaki çocuk profilinin normal gelişim gösteren çocuklar gibi yetersizliği ve gelişimsel geriliği olan çocukları da içerdiğini belirterek söz konusu üç program için birleşik bir sistem oluşturulmasının gerekliliğini vurgulamışlardır. Bu alanlardaki öğretmen adaylarının, uygulama yaptığı EÇ, EM ve EÇÖE'i kurumlarını Uygulama Ortamları ve bu ortamlardaki çalışmalarını da Uygulama Deneyimleri olarak isimlendirerek ortak bir terminolojinin kullanılması gerektiğini ifade etmişlerdir. Kaynaştırma uygulamalarında etkili müdahale yöntemlerini uygulayabilecek öğretmenler yetiştirebilmek için, öğretmen adaylarının Uygulama Ortamları'nda gerçekleştireceği Uygulama Deneyimleri'nin çok önemli olduğunu ifade etmişlerdir.

Okul öncesi eğitimde kaynaştırma uygulamalarına ilişkin ülkemizde yapılan çalışmalar incelendiğinde kaynaştırma uygulamalarında başarıyı etkileyen en önemli aktörlerden birinin sınıf öğretmeni olması sebebiyle, bu alandaki çalışmaların okul öncesi eğitimi öğretmenlerinin olumlu (Özbaba, 2000; Sünbül ve Sargın, 2002) ve olumsuz tutumlarını (Güven ve Önder, 1995; Seçer, Çeliköz, Sarı, Çetin ve Büyüktaşkapu, 2010) belirleme konusunda yoğunlaştığını göstermektedir. Bir diğer grup araştırmanın, okul öncesi öğretmen adaylarının hizmet öncesi kaynaştırma ve özel eğitim dersini almalarının kaynaştırmaya ilişkin görüşlerine etkisini belirleme konusunda yürütüldüğü görülmektedir (Kayılı, Koçyiğit, Doğru ve Çiftçi, 2010; Şahbaz ve Kalay, 2010). $\mathrm{Bu}$ araştırmalar tutum ve görüş ölçeklerinin kullanıldığ 1 nicel araştırmalardır. Oysa artık okul öncesinde kaynaştırma eğitiminin var olan durumunu saptamaktan çok çözüm odaklı ve bu alanda görev yapan anahtar kişilerin duygu ve düşüncelerini, görüşlerini derinlemesine incelemek ve bu kişilerin özellikle uygulamalara yönelik önerilerini daha ayrıntılı belirlemek gerekmektedir. Ülkemizdeki çalışmalar incelendiğinde, okul öncesi eğitimde kaynaştırma uygulamalarına ilişkin okul 
öncesi öğretmenlerinin görüşlerini belirlemeye yönelik üç nitel araştırmaya ulaşılmıştır (Altun ve Gülben, 2009; Gök ve Erbaş, 2011; Varlıer ve Vuran, 2006).

Altun ve Gülben (2009) tarafindan yapılan araştırmada, okul öncesi eğitimde özel gereksinimli çocukların tespiti, bu çocukların eğitimine yönelik uygulanan yöntemler ve kaynaştırma uygulamalarında yaşanan sorunların öğretmen görüşleri açısından değerlendirildiği görülmektedir. Trabzon ili merkezindeki okul öncesi eğitim kurumlarında çalışan 10 okul öncesi öğretmeni ile yürütülen çalışmanın verilerinin yarı yapılandırılmış görüşme tekniğiyle elde edildiği tespit edilmiştir. Araştırmanın sonuçlarına ilişkin, öğretmenlerin çoğunluğunun özel eğitim konusunda yeterli bilgiye sahip olmadıkları ve bu nedenle özel gereksinimli çocukların eğitimlerini destekleme açısından yetersiz kaldıkları yönünde bulgular elde edilmiştir. Okul öncesi öğretmenlerine yönelik hizmet içi eğitim faaliyetlerine yer verilmesi araştırmanın önerileri arasında ifade edilmiştir.

Gök ve Erbaş (2011) tarafından yürütülen araştırmanın okul öncesi eğitim kurumlarında görev yapan ve sınıflarında kaynaştırma öğrencisi bulunan okul öncesi öğretmenlerinin kaynaştırmaya ilişkin görüşleri ve önerileri belirlenmiştir. Nevşehir il merkezindeki okul öncesi eğitim kurumlarında görev yapan 10 okul öncesi öğretmen ile yürütülen çalışmada, öğretmenlerin kaynaştırma eğitiminin gerekliliği konusunda olumlu görüşlere sahip oldukları belirlenmiştir. Ancak, öğretmenler, kaynaştırma eğitimi konusunda çok az bilgi sahibi oldukları için kaynaştırma uygulamalarında yetersiz kaldıklarını ve dolayısıyla sınıflarında sorunlar yaşandığını bildirmişlerdir. Öğretmenlerin çoğunluğunun, görme ve ileri derecede zihinsel yetersizliği olan çocukların okul öncesi eğitim kurumlarında kaynaştırılmasının uygun olmadığını ifade ettikleri görülmektedir. 
Varlıer ve Vuran (2006) tarafindan yapılan çalışmada, okul öncesi eğitimi öğretmenlerinin özel gereksinimli çocukların kaynaştırma yoluyla eğitilmelerine ilişkin görüşlerinin belirlendiği görülmektedir. Eskişehir il merkezindeki ilköğretim okullarının ana sınıfları ve bağımsız anaokullarında görev yapan ve kaynaştırma öğrencisi deneyimi yaşayan 30 bayan öğretmenle yürütülen çalışmada öğretmenlerin, tümünün özel gereksinimli çocukların okul öncesi eğitim alması gerektiğini düşündüğü ve çoğunluğunun da bu çocuklar için okul öncesi eğitimin kaynaştırma yoluyla yürütülmesinden yana oldukları tespit edilmiştir. Araştırmaya katılan öğretmenlerin, okul öncesi eğitimde yaşanan sorunların çözümüne yönelik olarak; seminer, konferans ve toplantılar aracılığ 1 ile bilgilendirilmelerini istedikleri ve sınıf mevcutlarının sınırlı tutulmasını önerdikleri görülmektedir.

Ülkemizde, okul öncesi eğitimden yüksek öğretime, örgün eğitimden yaygın eğitime kadar ülke nüfusunun geniş bir grubunun eğitim ve öğretiminin sürdürülmesi, geliştirilmesi ve denetlenmesinden sorumlu olan tek birim MEB'dir. MEB, eğitim ve öğretim sorumluluğunun yanı sıra "Hayat Boyu Öğrenme" ilkesi kapsamında, merkez ve taşra teşkilatında görevli tüm öğretmenlerin, mesleki ve kişisel yeterlik açısından hizmet öncesi eğitiminden kaynaklanan eksikliklerini tamamlamak, eğitim alanındaki değişimlerin gerektirdiği bilgi, beceri ve davranışları kazandırmak için hizmet içi eğitimlerinden de sorumlu olan birimdir. Hizmet içi eğitim faaliyetleri, hizmet içi eğitim enstitülerinde ya da diğer okul ve kuruluşların bünyesinde sürdürülmektedir. $\mathrm{Bu}$ eğitimlere katılan öğretmenlerin, birbirinden farklı yaş grupları ve bireysel farklılıkları olan öğrenci grupları ile çalıştıkları göz önüne alındığında, çoğunlukla kurumlarda sürdürüldüğü görülen hizmet içi eğitim faaliyetlerinin öğretmenlerin ve öğrencilerin bireysel ihtiyaçlarını karşılamakta yetersiz kaldığı düşünülmektedir. Bu doğrultuda, iş ba- 
şında eğitim, danışmanlık hizmetleri gibi öğretmenlere sınıf ortamında eğitim, rehberlik ve danışmanlık yapılabilecek yeni hizmet içi eğitim modellerine gereksinim duyulduğu görülmektedir.

Okul öncesi eğitimin mevcut durumu ve kaynaştırma uygulamalarına ilişkin incelenen literatür doğrultusunda, bu çalışmanın amacı, “Okul Öncesi Eğitimde Kaynaştırma Eğitimi Hizmet İçi Eğitim” faaliyetine katılan ve en az bir eğitim öğretim yılı sınıfına özel gereksinimli bir öğrencinin yerleştirilmesi ile kaynaştırma deneyimi yaşayan okul öncesi öğretmenlerinin; a) kaynaştırma eğitimine ve b) katıldıkları “Okul Öncesi Eğitimde Kaynaştırma Eğitimi” hizmet içi eğitim programına ilişkin görüşlerini belirlemektir.

\section{Yöntem}

\section{Hizmet İçi Programının İçeriği}

Millî Eğitim Bakanlığı Hizmet İçi Eğitim Daire Başkanlığınca okul öncesi öğretmenleri için 2010-2011 eğitim öğretim yılı yaz döneminde, 3-7 Ağustos 2011 tarihleri arasında Yalova'da “Okul Öncesi Eğitimde Kaynaştırma Eğitimi ” hizmet içi eğitim programı düzenlenmiştir. Bu programın içeriği:

(a) Kaynaştırmanın tarihçesi ve mevzuat

(b) Kaynaştırmanın okul öncesi eğitimdeki yeri

(c) Kaynaştırmanın felsefi ve bilimsel dayanakları

(d) Kaynaştırmanın tanımı

(e) Kaynaştırmada rol oynayan etmenler 
(f) Destek özel eğitim hizmetleri

(g) Özel eğitimde ek hizmetler

(h) Kaynaştırma sınıflarında yapılabilecek olası düzenlemeler

(i) Kaynaştırma ortamlarında öğretimsel uyarlamalar

(j) Okul öncesi dönemde sosyal kabul ve sosyal beceri

(k) Etkili öğretim yöntemleri

(1) Farklı özür grupları için öğretmenlere pratik öneriler

Yukarıda belirtilen konular, eş zamanlı olarak iki uzman tarafından iki ayrı gruba anlatılmıştır. Programın süresi beş iş günü, toplam 30 saattir. Bu programa ülkemizin farklı coğrafi bölge ve illerinden gelen toplam 40 okul öncesi öğretmen katılmıştır.

\section{Katılımcıların Özellikleri}

$\mathrm{Bu}$ araştırmanın katılımcılarını, yukarıda sözü geçen hizmet içi programına katılan dokuz okul öncesi öğretmeni oluşturmuştur. Araştırmacılar programın dördüncü günü ders sonrasında araştırma amaçlarını ve bunun için de görüşlerini almak istediklerini, bu amaçla da her gruptan dört kişi ile görüşme yapmak istediklerini açıklamışlardır. Ayrıca bu çalışmaya katılımda gönüllülük ilkesine göre davranılacağı belirtilmiştir. Araştırmaya katılmak isteyenlerin isimlerini kendilerine yazdırmalarını istemişlerdir. İki gruptan dört katılımcı planlanırken bir gruptan bir öğretmen bu çalışmaya katılmayı çok istediğini ifade ettiği için katılımcı sayısı dokuz olmuştur. Katılımcıların demografik özellikleri Tablo 1'de açıklanmaktadır. 
Tablo 1. Katılımcıların demografik özellikleri

\begin{tabular}{|c|c|c|}
\hline Demografik değişkenler & & Sayı $(N)$ \\
\hline \multirow[t]{2}{*}{ Cinsiyet } & Kadın & 9 \\
\hline & Erkek & 0 \\
\hline \multirow{2}{*}{ Yaş } & $28-35$ & 5 \\
\hline & $36-44$ & 4 \\
\hline \multirow{2}{*}{ Deneyim yılı } & $6-12$ & 5 \\
\hline & $13-21$ & 4 \\
\hline \multirow{2}{*}{ Kaynaştırma deneyim yılı } & $2-4$ & 5 \\
\hline & $5-6$ & 4 \\
\hline \multirow{3}{*}{ Mezun olduğu program } & Okul öncesi öğretmenliği & 5 \\
\hline & $\begin{array}{l}\text { Çocuk gelişimi ve okul } \\
\text { öncesi öğretmenliği }\end{array}$ & 3 \\
\hline & $\begin{array}{c}\text { Açık öğretim okul öncesi } \\
\text { öğretmenliği }\end{array}$ & 1 \\
\hline \multirow{2}{*}{ Çalışılan kurum } & İlköğretime bağlı ana sınıfi & 5 \\
\hline & Bağımsız anaokulu & 4 \\
\hline
\end{tabular}

Katılımcıların hepsi kadındır ve yaş ortalaması 33,5'dur. Mesleki deneyim yıllarının ortalaması 11, kaynaştırma deneyim yılları ise 4'tür. Katılımcıların çoğu (5) dört yıllık lisans programlarından okul öncesi öğretmenliği mezunudur. Biri ise, Anadolu Üniversitesi Açık Öğretim Fakültesi Okul Öncesi Öğretmenliği programından mezundur. Katılımcıların şu an çalıştıkları kurumlara göre dağılımları ise, çoğu (5) ilköğretime bağlı ana sınıfında, dördü bağımsız anaokulunda çalışmaktadırlar.

\section{Araştırma Modeli}

Bu araştırmada, "Okul Öncesi Eğitimde Kaynaştırma Eğitimi”" hizmet içi eğitim faaliyetine katılan ve en az bir eğitim öğretim yılı sınıfına özel gereksinimli bir öğrencinin yerleştirilmesi ile kaynaştırma deneyimi yaşayan okul öncesi öğretmenlerinin; a) kaynaştırma eğiti- 
mine ve b) katıldıkları "Okul Öncesi Eğitimde Kaynaştırma Eğitimi”" hizmet içi eğitim programına ilişkin görüş ve önerilerini derinlemesine elde etmek amaciyla odak grup görüşmesi tekniği ile gerçekleştirilen nitel verilere dayalı bir durum çalışmasıdır.

\section{Verilerin Toplanması}

Nitel verilere dayalı bir durum çalışması olan bu araştırmada, ihtiyaç duyulan veriler araştırmacılar tarafından geliştirilen ve 13 soruyu kapsayan bir görüşme formu kullanılarak toplanmıştır. Veriler araştırmacılar tarafından geliştirilen ve bir uzman görüşü alınarak şekillendirilen 13 soruyu kapsayan bir görüşme formu hazırlanmıştır. Görüşme formu; “Görüşmeci Bilgi Formu” ve “Görüşme Soru Formu” olmak üzere iki bölümden oluşmaktadır (Ek 1). Katılımcılar belirlendikten sonra, görüşme zamanı için öncelikle katılımcılara ve araştırmacılara uygun olan saat belirlenmiştir. Görüşme zamanı olarak herkes için uygun olan o günün (dördüncü gün) akşam yemeğinden bir saat sonra olan akşam saati belirlenmiştir. Aynı gün araştırmacılar, kurum yetkilisinden akşam için toplantı yapabilecekleri bir oda ve ikram için çay-kahve hizmeti talebinde bulunmuşlardır. Kurum yetkilisi araştırmacıların bu taleplerini memnuniyetle karşılayabileceklerini ifade etmiştir. Toplantı odası olarak, hizmet içi programına katılan bir gruba eğitimin verildiği eğitim odası belirlenmiştir. Odada 15 kişilik bir masa ve sandalye, projeksiyon ve bir klima bulunmaktadır. Toplantı bir saat 45 dakika sürmüştür (21:00-22:45). Görüşmede katılımcılardan yazılı ve sözel olarak görüş alınmıştır. Odak grup toplantısı bir yönlendirici (I. araştırmacı) ve bir yönlendirici yardımcısı (II. araştırmacı) tarafından yürütülmüştür. Toplantının akışı aşağıda maddeler olarak sıralanmaktadır:

1. Katılımcıların karşılanması

2. Katılımcıların isimlerinin yazılı olduğu kâğıtların masaya yerleştirilmesi 
3. Katılımcılarla görüşme konuları dışında sohbet etme

4. Yönlendiricinin açı1ışı yapması

Toplantının açılışında izlenen aşamalar:

1. "Hoş geldiniz" denilerek katılımları için teşekkür edilmiştir.

2. Toplantının konusu/amacı tekrarlanmıştır.

3. Toplantı sırasında uyulması gereken kurallar açıklanmıştır. Görüşmede uyulması gereken kurallar ise aşağıda belirtilmektedir.

- Öncelikle görüşme formlarına yazılı olarak cevap verilecek.

- Daha sonrasında sözel olarak gerçekleştirilecek grup görüşmesinde ses kaydı yapilacak.

- Ses kaydı araştırmacılar dışında kimseyle paylaşılmayacak (gizlilik ilkesi).

- Katılımcıların isteği doğrultusunda isimleri gizlenecek ve her birine kod ismi verilecek.

- Kayıtların anlaşılabilmesi için her bir katılımeı teker teker söz alacak.

- Ses kaydının dökümünde karışıklık olmaması için katılımcılar söz aldıklarında kod isimlerini söyleyerek konuşmalarına başlayacaklar.

Yazı1ı olarak görüşlerin alınmasından sonra görüşme formları toplanmış ve yönlendirici, hazırlanan görüşme sorularını katılımcılara tekrar yöneltmiştir. Katılımcılardan soruya ilişkin cevapları, cevaplarına eklemek istedikleri ya da özellikle önemli gördükleri ve kayda geçmesini istedikleri görüşleri alınmıştır. Yönlendirici, anlaşılmayan yerler olduğunda ya da konu dağıldığında katılımcıları yönlendirmiştir. Gerekirse yönlendirici yardımcısı da devreye girmiștir. Yönlendirmeler sırasında olumlu ya da olumsuz dönüt vermekten kaçınılmıştır. Sözlü ya da jest ve mimiklerle katılımları için teşvik edilmiştir. Görüşmeler 
sırasında yönlendirici kısa notlar, yönlendirici yardımcısı ise ayrıntılı notlar almıştır. Görüşme sonlarında yönlendirici yardımcısı, konuşulanları kısaca özetleyerek konunun toparlanmasını sağlamıştır. Yönlendirici görüşmeleri sonlandırırken katılımcılara eklemek istedikleri bir şey olup olmadığını sormuş ve katılımları için tekrar teşekkür etmiştir. Görüşmenin bitiminde, katılımcılara soğuk-sıcak içecek ikram edilmiştir.

\section{Verilerin Analizi}

Toplanan veriler; verilerin dökümü, verilerin kodlanması, temaların bulunması, kodların ve temaların organize edilmesi işlemlerini kapsayan içerik (tümevarım) analizi tekniği ile analiz edilmiştir (Baxter ve Jack, 2008; Yıldırım ve Şimşek, 2000). Odak görüşmesinden sonra, ses kayıtlarının yazıya dökümü yapılmıştır. Döküm yapılırken konuşmalar aynen, hiç düzeltme yapılmadan gerçekleştirilmiştir. Döküm işleminin ardından veriler, bilgisayarda bir form üzerine yüklenmiştir. Ses kaydının bilgisayar ortamındaki dökümü toplam 23 sayfa ve 726 satırdır. Daha sonrasında verilerin güvenirlik çalışması amacıyla hem görüşmenin ses kaydı hem de yazılı dökümleri bir uzman tarafından dinlenmiş ve okunmuştur. Uzman dökümlerin doğru olup olmadığını kontrol etmiş ve eksik olan yerleri tamamlamıştır. Bu çalışmalar tamamlandıktan sonra, elde edilen verilerden kategoriler oluşturulmuş ve kodlamalar yapılmıştır. Bu aşamadan sonra temalar ve alt temalar oluşturulmuştur. $\mathrm{Bu}$ çalışmaları, iki araştırmacı bağımsız olarak ayrı yer ve zamanlarda gerçekleştirmiştir. Daha sonrasında araştırmacılar bir araya gelerek, oluşturulan kodlar, temalar ve alt temalar üzerinde görüş birliği ve görüş ayrılıklarını kontrol etmişler ve uzlaşma çalışması yapmışlardır. Nitel araştırmalarda "üçleme/çeşitleme" denilen (Data triangulation) geçerlik ve güvenirlik çalışmasını sağlamak amacıyla ses kayıt dökümlerinin dışında katılımcılardan yazılı olarak da görüş alınmıştır (Brantlinger, Jimenez, Klingner, Pugach ve Richarson, 2005). Katılımcılar, görüş- 
me formundaki sorulara yazılı olarak cevaplarını yazmışlardır. Yazılı olarak alınan görüşler, oluşturulan tema ve alt temaların paralelliğinde destek veri olarak kullanılmıştır. Tüm bu çalışmaların sonunda alandan bir uzman, oluşturulan temaları ve alt temaları incelemiş ve gerekli olan düzenlemeler araştırmacılar tarafından gerçekleştirilmiştir. Bu işlemler sonunda, elde edilen verilerden üç tema ve her bir temanın da alt temalarına ulaşılmıştır.

\section{Bulgular}

Araştırmanın bulgularını araştırmaya katılan okul öncesi öğretmenlerin görüşme formundaki sorulara hem yazılı hem de sözel olarak alınan cevaplardan elde edilen 3 tema ve bu temaların alt temaları oluşturmaktadır. Araştırma bulguları, görsel olarak Şema 1'de gösterilmektedir. 

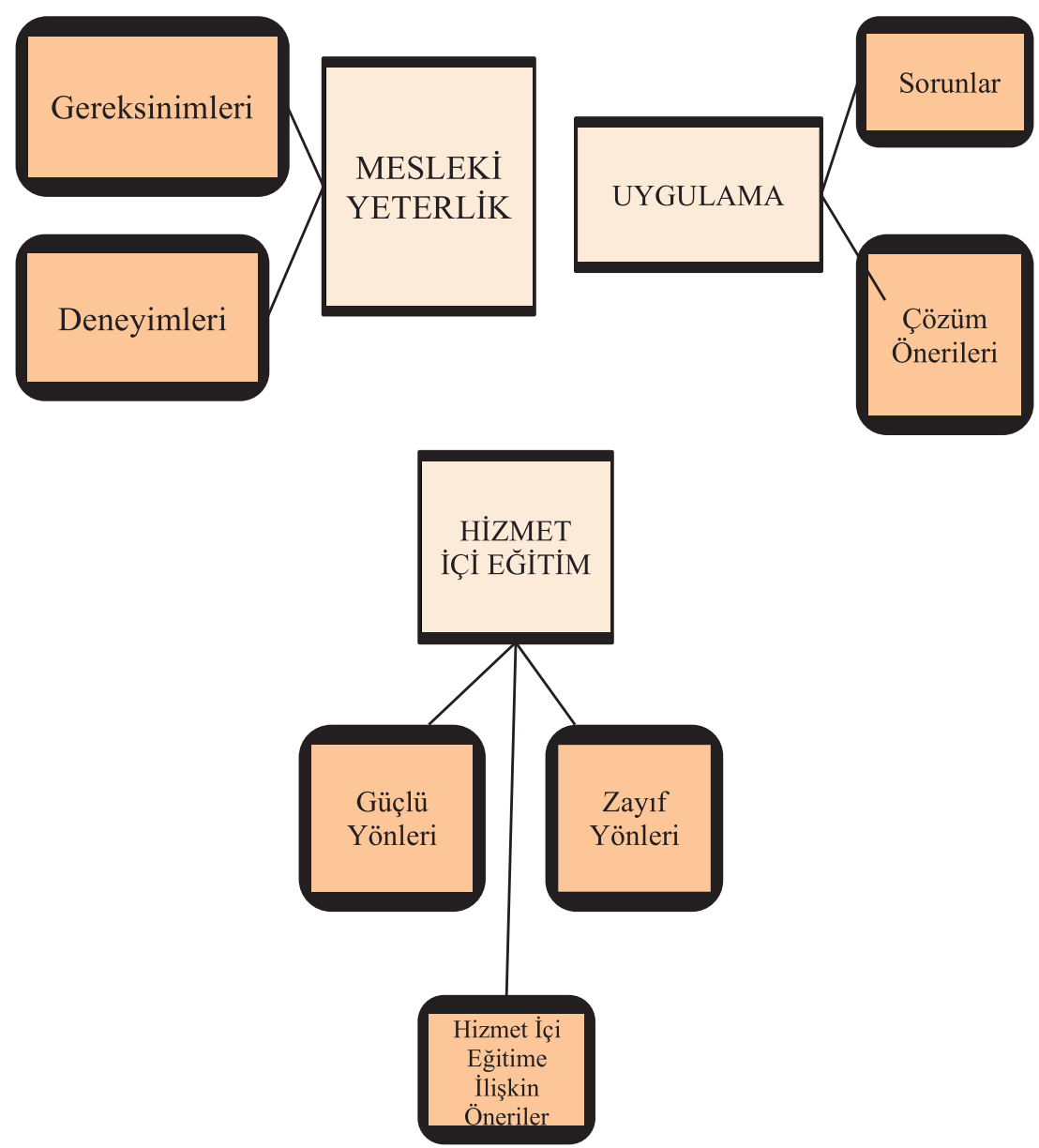

Şema 1. Tema ve alt temalar

İzleyen bölümde tema ve alt temalara ilişkin açıklamalar ve alıntılar yer almaktadır.

\section{Öğretmenlerin Mesleki Yeterlikleri}

Görüşme yapılan öğretmenlerin mesleki yeterlik temasında, öğretmenlerin kaynaştırma eğitimi ve katıldıkları hizmet içi eğitim programına yönelik görüşlerinden kendi gereksinimleri ve alandaki deneyimleri alt temaları elde edilmiştir.

Öğretmenlerin gereksinimleri: Görüşme yapılan öğretmenlerin 
büyük çoğunluğu, kaynaştırma konusunda bilgi gereksinimi, ailelere bu konuda bilgi vermek istemeleri, kaynaştırma öğrencilerine her konuda yardımc olmak istemeleri ve kendi mesleki bilgi ve becerilerini geliştirmek yönünde gereksinimleri olduğunu ve bu nedenle düzenlenen hizmet içi eğitim programına katıldıklarını ifade etmişlerdir. Bu görüşlere ilişkin alıntılara örnekler: İlke, "Kaynaştırma öğrencisine faydalı olmak için” (satır 3). Cennet, "Kaynaştırma öğrencilerinin ailelere ulaşabilmek için buradayım" (satır 2). Serpil Bursa, "Sinıfimda bir tane görme engelli, bir tane epilepsi hastast ve zihinsel engelli, bir tane de otistik öğrenci ile tanıştım. Bu kadar çok engel çeşidinin olduğu çocuklarla karşılaşınca kaynaştırma anlamında destek almam gerektiğini düşündüm. Engel dört farklı yetersizliği olan çocuk var” (satır 15-23). Gül, “Kendimde büyük eksikler gördüm”(satır 4).

Öğretmenlerin deneyimleri: Öğretmenlerin lisans düzeyinde ya da lisans sonrası mesleki dönemlerinde özel eğitim ve kaynaştırma ile ilgili deneyimleri sorulduğunda öğretmenlerin çoğu lisans dönemlerinde özel eğitim derslerini seçmeli ders olarak aldıklarını ya da il kapsamında düzenlenen seminerlere katıldıklarını ifade etmektedirler. Bu görüşleri betimleyen alıntılara örnekler: Rapunzel, "Lisans eğitimim sırasında Özel Eğitim I ve II adı altında iki dönem ders almıştım” (satır 7-9). Beyaz Kelebek, "Il bazında düzenlenen 30 saatlik mahalli seminere katılmıştım”"(satır 4-6). Serpil Bursa, "Biz şimdi üniversitede aldı̆̆ımız eğitimde özel eğitim, yüzeysel özel eğitim dersi aldık ama kaynaştırma ĕgitimini daha böyle ayrıntılı şekilde almadık yani daha böyle görme engelli çocukla nasıl ĕgitim yapılır? Isşte zihinsel engelliyle nasıl ĕgitim yapılır? Bu gibi konularda ĕgitim almadık.” (satır 58-62).

\section{Hizmet İçi Eğitim Programı}

Öğretmenlerden hizmet içi programına yönelik görüşler alındığında, programın içeriği, süresi, uzmanların yeterlilikleri ve ders 
işleyişleri konularında yoğunlaştıkları görülmüştür. Öğretmenlerin büyük çoğunluğu, hizmet içi eğitim programının beklentilerini karşıladığını, içeriğin yeterli ve kapsamlı olduğunu ve yeni bilgiler öğrendiklerini ifade etmişlerdir. Öğretmenlerin eğitim uzmanlarının kendi alanlarında çok donanımlı olduklarını, tecrübeleri ve örnekleri ile konulara hâkim olduklarını ayrıca sosyal olarak da kendilerine yaklaşımlarının olumlu ve samimi olduklarını belirtmişlerdirler. Çoğu öğretmen, program süresinin yeterli olduğunu ancak üç öğretmen sürenin biraz daha uzun olabileceğini ifade etmişlerdir. Örnek alıntılar; Zübeyde, "Etkili güzel bir seminerdi. Arkadaşlarla deneyimlerini paylaşttk. Hocamız etkiliydi, bizi bilgilendirdi să̆ olsun. Güzeldi, etkiliydi ama bir tek şeyi vardı zamanlama kötüydü, ramazan olması" (satır 414-417). Beyaz kelebek, "Beklentilerimin çoğunu karşıladı aslında seminer" (satır 315). Elvinnur, "Hocamız bilgi donanımını çok güzel ve akıcı bir şekilde karşılıklı söz alışverişiyle destekleyerek sundu" (satır 37-39). Ordu, "Hocamızın örneklerle anlattığı konuları daha çok bilincime yerleşti. Bundan sonra engelli bir öğrenciyle karşılaş̧tı̆̆ım zaman daha bilgili, panik olmadan ona faydalı olmaya çalışacağım" (satır 433-436). Rapunzel, "Uzmanlarımızın alanlarında yeterli olduklarını düşünüyorum. Eğitim sürecinde vermişs oldukları bilgiler olsun iletişim yeterliği olsun, sinıf yönetimi olsun, anlatım becerileri açısından da başarılı oldukları kanaatindeyim" (satır 49-52); "Program süresi yetersizdi. Bu süre daha uzun olup konuların çeşitliliği arttırılabilir" (satır 56-57); Cennet "Süre azdı" (sattr 33).

Programın güçlü yönleri: Öğretmenlerle yapılan görüşmelerde çoğu hizmet içi programının etkili olduğunu, bu alanda çalışan meslektaşların bir arada olmasından dolayı yaklaşım ve tecrübelerin paylaşılmasının da çok etkili olduğunu belirtmişlerdir. Kaynaştırma öğrencilerine yönelik uygulayacakları yöntemleri öğrendiklerini, deneyim sahibi meslektaşlarıyla tanıştıklarını, bilgilerini tazelediklerini 
ve kalıc1 olan örnekler olduğunu ifade etmişlerdir. Bu görüşlere örnek alıntılar; Beyaz Kelebek: "Her türlü yetersizliği olan sınıfima gelecek ögrenciye karşı hazırlıklı olmamı sağladı” (satır 43-44). Ordu, "Kaynaştırma öğrencisine kazandırılacak öncelikli davranışlar konusunda bilgi sahibi oldum” (satır 35-38). Gül, “Bu konuda tecrübesi olan arkadaşların tecrübelerinden faydalandım" (satır 39-40), Cennet (39-41).

Programın zaylf yönleri: Öğretmenler hizmet içi programının zayıf yönlerine ilişkin çoğunlukla program süresinin azlığg ve uygunsuz bir zamanda olması (ramazan ayı), yurt dışındaki örnek uygulamaların olmaması ve bireyselleştirilmiş eğitim programlarının hazırlanmasına yönelik bilgilerin olmaması konularında görüş bildirmişlerdir. Bu görüşlere örnek alıntılar; Gül, "Örnekler de doyurucu oldu fakat görsel anlamda olsaydı yurt dişındaki uygulamalarla ülkemizdeki uygulamaları karşılaştırsaydık, o okulları görebilseydik mesela bizim hiç görmediğimiz okullar, bu tarz okullar. Yani o açıdan eksiklikler var" (satır 466-469). Zübeyde, "Çocuklarla birebir uygulama yapabilmeyi isterdim" (satır 29-31; 48-49). Beyaz Kelebek, "Uygulamalı eğitim yapılabilirdi” (satır 480). Rapunzel, "Uygulamalı eğitim yapılabilirdi....Bireysel eğitim programı hazırlama” (satır 59-60; 64). Elvinnur, "Sinıftaki arkadaşların derse daha fazla katılmaları iyi olurdu (satır 57-58).

Programa ilişkin öneriler: Öğretmenlere hizmet içi programına eklemek istedikleri ya da hangi konularda bilgi almak istedikleri sorulduğunda öğretmenlerden gelen başlıca konu önerileri; ailelere yönelik bilgiler, bireyselleştirilmiş eğitim programları, kaynaştırmadaki araç-gereçlerin tanıtımı ile ilgili konulardır. Bu görüşlere örnek alıntılar; Beyaz Kelebek, "Ben hemen söyleyim mesela BEP olabilirdi" (satır 475); Rapunzel (satır 63); Beyaz Kelebek, "Bir hafta teorik, bir hafta uygulamalı olabilirdi (satır 480); Rapunzel (satır 59-60). Zübeyde, 
"Annelerle, babalarla sorunlar yaşıyoruz hani isterdim ki birkaç saatlik o ailenin psikolojisi, onlara nasıl yaklaşacağız? Bu konuyla ilgili bilgilendirilmek, o konuda çok çok yetersizim. Kendim bir şey yapamıyorum. Aile neler düşünüyor, neler yapıyorlar? Sadece işte oraya da yazdığım gibi sabırlı olmalarını, acele etmemelerini, pes etmemelerini sadece bunları söyleyebilirim ama başka neler söyleyebilirim, nasıl destek olabilirim ya da onlar bana nasıl destek olabilir? Onları bilgilendirmem anlamında bu tip bilgimiz yok, böyle de bir şey olabilirdi"” (satır 491-499).

\section{Kaynaştırma Uygulamalarında Yaşanan Sorunlar}

Öğretmenlerin çoğu kaynaştırma uygulamalarında ailelerden destek almadıklarını, okul yönetimlerinden destek görmediklerini ve sınıf mevcutlarının çok kalabalık olduğunu belirtmişlerdir. Bu görüşlerini betimleyen alıntılara örnekler; Elvinnur, "Daha çok ailenin ilgi göstermediği en büyük sorun. Tek tarafl ĕgitim yeterli değil. Öğrenciöğretmen ilişkisiyle yeterli değil, velinin de katılımı, desteği gerekiyor. Çünkü havada kalmış oluyor sadece ögretmen bilgiyi verdiğinde. Bunu yaşamsal olarak aile uygulamaya geçecek. Bunun için ailenin katılımsızlığl ve bilgisizliği, ilgisizliğ çok problem oluyor. Ailenin katılımsızlı̆̆l ve ilgisizliği en çok sıkıntımız" (satır 48-54). Cennet, "Velilerin farklılıkları kabullenmede zorlanmaları sorunumuzdur" (satır 15). Beyaz Kelebek, "Benim sıkıntı yaşadığım noktalardan birisi, kaynaştırma sinıfinın sınıf mevcudunun çok fazla olması. Ben ilk geldiğim günden bunu vurguluyorum ben. 30 çocuğum var, bir de kaynaştırma öğrencim var” (satır 80-83). İlke, "Aileler çocuğunun durumunu kabullenmiyor" (satır 15). Serpil Bursa, "Sınıf mevcutları çok kalabalık, 25 kişi”" (satır 13-14); Cennet (satır 12). Cennet, "Okul idaresinin konuya yaklaşımı olumsuz” (satır 14). Gül, "Bilgi yetersizliği, araç-gereç ve materyal yetersizliği" (satır 11). 


\section{Sorunlara Yönelik Çözüm Önerileri}

Öğretmenler kaynaştırma ortamlarında karşılaştıkları sorunlara karşı daha çok kendi çabalarıyla bir şey yaptıklarını, genellikle yalnız kaldıklarını ifade etmişlerdir. Öncelikle ailelerle görüşmeler yaptıklarını, okulda varsa rehber öğretmenle görüştüklerini, RAM'a giderek uzmanlardan destek almaya çalıştıklarını ifade etmişlerdir.

Öğretmenlerin kendi çabalarına yönelik görüşlerden alıntılar şu şekilde özetlenebilir: Beyaz Kelebek, "Genelde okulumuzun rehber öğretmeninden yardım istedik bu konuda. Rehber ögretmenimizle görüşme yaptık, ben birebir görüşmeler yaptım. Bir de benim genelde velilerime uyguladı̆̆ım bir şey var. Ben her ay, 15 günde bir herhangi bir konuda, sene başında ihtiyaç belirleme formunda belirlediğim konulara yönelik velilerime bilgilendirmeye yönelik makaleleri de evlere gönderirim. Sorunu olan çocuğun aileye ayrı makaleler, o aileye özel, daha sık makaleler şeklinde bilgilendirme de yapıyorum” (satır 188-195). Zübeyde, "Bizlere yardım edebilecek kurum RAM. Çünkü en iyi bilgiye onlar sahip. O şekilde, aynen öyle. Ben arkadaşlara da öyle söylüyorum. Sonra aileyle, ama arkadaşların da dediği gibi ailelerin hiç desteği olmuyor desem yeridir" (satır 205-208). Rapunzel, "Internetten araştırarak, birilerine sorarak bu anlamda faydast oluyor" (satır 392-393). Gül, "Sonra bilgisayardan araştırdım" (satır 447).

Çözüm önerilerini; genel müdürlüğe, okul yönetimine, ailelere, uzmanlara ve meslektaşlarına yönelik öneriler olarak bildirmişlerdir. Genel müdürlüğe yönelik önerileri çoğunlukla, sınıf mevcutlarının yönetmeliğe uygun düzenlenmesi, kendilerine özel eğitim danışmanlığgnın verilmesi, sınıflarına yardımcı öğretmen verilmesi, fiziksel ortamların ve araç-gereçlerin düzenlenmesi, okul yöneticilerine bu konularda seminerler verilmesi şeklinde yoğunlaşmaktadır. Okul yönetimlerine 
yönelik önerileri; destek ve anlayış, materyal sağlama ve aile-okul iş birliğinde destek olmaları şeklindedir. Ailelere yönelik öneriler ise; öncelikle çocuklarını kabullenmeleri, okulla iş birliği yapmaları ve çocuklarının eğitim gereksinimlerini araştırmaları yönünde toplanmaktadır. Alandaki uzmanlara yönelik öneriler; MEB ile daha fazla iş birliği yaparak buna benzer seminerlerin her ilde daha çok yapılması, görsel örneklerle sunumların arttırılması, lisans öğrencilerinin uzmanlaşmaları konusunda onları teşvik etmeleri önerileri belirtilmiştir. Son olarak da kendi meslektaşlarına yönelik öneriler de şu konular yoğun olarak ifade edilmiştir: Özel gereksinimli öğrenciyi kabul etmeleri, işlerini severek ve araştırarak yapmaları, etkinlikleri öğrencinin özelliklerine göre uyarlayarak düzenlemeleri ve aile-okul işbirliğinde öncü olmaları. Önerilere ek olarak öğretmenlere kendilerine hangi destek özel eğitim hizmetini istedikleri sorulduğunda, özel eğitim danışmanlığı, sınıfta yardımcı bir öğretmen ve kaynak oda desteği olarak görüşlerini bildirmişlerdir.

Öğretmenlerin önerilere yönelik görüşlere örnek alıntılar; Serpil Bursa, "İlköğretimlerde böyle şeyler yaşanabiliyor. Bütün okul müdürlerinin ve hatta müfettişlerin özel eğitim seminerlerine gitmesi gerekiyor” (satır 115-116). Beyaz Kelebek, “Okulumuzda, özel eğitim danışmanının olması geri bildirim almamızı sağlayacaktır”; "Bu konuda idarecilerin ögrencinin durumunu belki okul açılmadan en azından bir hafta, on gün öncesinden öğretmene açıklaması, bizim ona küçük bir materyal bile olsa hazırlamamızı sağlar" (satır 272-275). Cennet, "Zaten ögretmen bunu yapmazsa olmaz zaten. Öğretmen bu işi severek yaparsa olur" (satır 291-292). Beyaz Kelebek, "Millî Eğitim'in bence özel eğitim danışmanlarından, uzmanlarından oluşan bir ekip oluşturup yani ben kendimden bir özel ĕgitim danışmanı istiyorum. Evet. Evet. Kaynaştırma öğrencisi olan okullara haftada en az bir gün uğrasa dahi 
bir özel eğitim danışmanlığı yapılabilir. Bunu da niçin böyle söylüyorum, eleman azlığından bahsettiğiniz için söylüyorum. Yoksa her okulda bir özel eğitim ögrretmeninin olması gerekiyor” (satır 510-516). Rapunzel, "Mahalle seminerleri de verilebilir bu konularda. Daha sonra özel eğitim danışmanlı̆̆ bizlere yapılabilir. Aynı zamanda bu ailelere de yapılabilir" (satır 531-533); "Okullaşma oranı arttı deniyor, okul öncesinde biz geliştik diyoruz. Ama nitelik yok, kalite yok. Saylsal verilerden ziyade bence önemli olan, ne kadar nitelikli bir eğitim yaptı̆̆gmiz. Oyüzden bu şeyi birimin en başından en sonuna kadar bunlara çok önem verilmesi gerekiyor ve kesinlikle bunların, okul müdürlüklerinin denetlenmesi gerekiyor. Okul müdürlerini zorlamak yerine aslında zaten 'burada kaynaştırma öğrencisi var neden iki tane?' olmaması lazım ya da 'bir tane var. O zaman neden bu sinif 33?' bunların mutlaka denetlenmesi lazım. Müfettişler bizi denetliyorlar, hani yaptı̆̆ımız angaryalarl denetliyorlar. Bunlar denetlensin yani işin niteliği denetlensin. Sayısal verilere takılmasın, ne kadar nitelikli eğitim verildiğine bakılsın" (satır 650-662). Serpil Bursa, "Sınıf dışında hem çocuk orda birebir özel eğitimini alacak, sonra sınıfina girecek kaynaştırma eğitimini alacak. Yani aynı kurumda" (satır 547-548). Cennet, "Yardımcı asistan diye yazdlk oraya zaten" (satır 558). Ordu, "Şimdi hocam aynen bizim seminere katıldığımı gibi ana sınıfı öğretmen arkadaşlarımızın da bu seminerlere katılmalarını ben istiyorum. Çünkü bu seminerlerin yararlı olduğuna çok inanıyorum. Bir de hocam şey, bu arkadaşlarımızın, kaynaştırma öğrencisi okutan ögretmenlerimizin sabır, ondan sonra veliyle iş birliği içinde olmasını istiyorum” (satır 577-582). 


\section{Tartışma}

Uluslararası alan yazın tarandığında, okul öncesi eğitimde kaynaştırma çalışmalarında, okul öncesi öğretmenlerinin yetersizliği olan çocuklara destek olabilmek için müdahale programları konusunda eğitime gereksinimleri olduğu (Odom, McConnell ve Chandler, 1994), ve öğretmenlerin bu çocuklarla uygulama yapabilme konusundaki algılarının, zaman, bilgi düzeyleri, kaynaklara ulaşım, fiziksel mekân ve normal gelişim gösteren akranların yetersizliği olan çocuğu kabul düzeyleri gibi farklı değişkenlerden etkilendiğine (Odom, 2000) dikkat çekildiği görülmektedir. Bu alandaki son çalışmaların ise okul öncesi öğretmenlerinin, müdahale programına daha sık gereksinim duydukları (Rheams ve Bain, 2005), erken öğrenme standartları konusunda danışmanlık hizmetlerine gereksinimleri olduğu (Scott-Little, Kagan ve Frelow, 2003) ve hizmet öncesi öğretmen adaylarının mezuniyet sonrası çalışacakları Uygulama Ortamları'nda Uygulama Deneyimleri kazanmalarının öneminin vurgulandığı görülmektedir (Macy, Squiers ve Barton, 2009). Ülkemizde bu alanda yapılan çalışmaların ise sınırlı olduğu ve daha çok okul öncesi öğretmenlerinin kaynaştırma konusundaki tutumlarını belirlemeye yönelik olduğu görülmektedir (Güven ve Önder, 1995; Özbaba, 2000; Seçer, Çeliköz, Sarı, Çetin ve Büyüktaşkapu, 2010; Sünbül ve Sargın, 2002).

Ülkemizde, okul öncesi öğretmenlerinin yaşadıkları en büyük sorunun; kaynaştırma eğitimine ilişkin donanımlarının olmayışından kaynakladığı görülmektedir. Araştırmanın bulguları arasında yer aldığı gibi, öğretmenlerin büyük çoğunluğunun, kaynaştırma konusunda bilgi gereksinimi, ailelere bu konuda bilgi vermek istemeleri, kaynaştırma ögrencilerine her konuda yardımcı olmak istemeleri ve kendi mesleki bilgi ve becerilerini geliştirmek yönünde gereksinimleri olduğu tespit edilmiştir. Bu nedenle okul öncesi öğretmenlerine sunulan tek destek uygulama olan kaynaştırma ve özel eğitim alanında düzenlenen hiz- 
met içi eğitim programına katıldıklarını ifade ettikleri görülmektedir. Okul öncesi öğretmenlerinin kaynaştırma eğitimi konusunda hizmet içi eğitimlere gereksinimleri olduğu bu alanda yapılan çalışmaların önerileri arasında da yer almaktadır (Altun ve Gülben, 2009; Gök ve Erbaş, 2011; Varlıer ve Vuran, 2004). Okul öncesi öğretmenlerinin kaynaştırma ile ilgili deneyimlerinin, lisans düzeyinde seçmeli ders olarak aldıkları özel eğitim dersi (Kayılı, Koçyiğit, Doğru ve Çiftçi, 2010; Şahbaz ve Kalay, 2010) ya da lisans sonrası hizmet içi eğitim ve il kapsamında düzenlenen seminerler yoluyla olduğunu ifade ettikleri görülmektedir. Okul öncesi eğitimde kaynaştırma eğitiminin 1997 y1lından itibaren zorunlu eğitim kapsamında olduğu düşünüldüğünde, Yüksek Öğretim Kurulu'nun söz konusu öğretmenlik programlarının; öğretmen adaylarının kaynaştırma eğitimi ortamlarında, müdahale programlarını uygulayabilme deneyimi kazanacak biçimde yetiştirilmelerini gerektirecek biçimde yeniden düzenlenmesinin gerekli olduğu görülmektedir (Macy, Squiers ve Barton, 2009).

Okul öncesi öğretmenlerinin hizmet içi programına ilişkin görüşlerinin, programın içeriğii, süresi, uzmanların yeterlilikleri ve ders işleyişleri konularında yoğunlaştığı görülmektedir. Öğretmenlerin büyük çoğunluğu, hizmet içi eğitim programının beklentilerini karşıladığını, içeriğin yeterli ve kapsamlı olduğunu ve yeni bilgiler öğrendiklerini ifade etmişlerdir. Okul öncesi eğitimi öğretmenlerine kaynaştırma eğitimi konusunda mevcut durumda ulaşan tek desteğin MEB ya da il boyutunda düzenlenen hizmet içi eğitimler olduğu görülmektedir. Hizmet içi eğitimlerin şu anda sistemde görevli okul öncesi öğretmenleri için önemli olduğu bu alanda yapılan çalışmaların önerileri arasında da yer almaktadır (Altun ve Gülben, 2009; Gök ve Erbaş, 2011; Varlıer ve Vuran, 2004). Öğretmenlerin; eğitim uzmanlarının kendi alanlarında çok donanımlı olduklarını, tecrübeleri ve örnekleri ile konulara hâkim olduklarını ayrıca sosyal olarak da kendilerine yaklaşımlarının olumlu 
ve samimi olduklarını belirttikleri görülmektedir. Araştırmanın, öğretim görevlilerine ilişkin olumlu bulgularının, MEB Hizmet İçi Daire Başkanlığı'nın eğitimlere katılacak öğretim görevlilerinin tespitinde üniversiteler ile iş birliği içinde planlama yapmalarının olumlu sonuçları olarak değerlendirilmektedir. .

Okul öncesi öğretmenlerinin hizmet içi eğitim programının güçlü yönleri arasında; bu alanda çalışan meslektaşları ile yaklaşım ve tecrübelerin paylaşılmasının etkili olduğunu ve kaynaştırma öğrencilerine yönelik uygulayacakları yöntemleri öğrendiklerini belirttikleri görülmüştür. Okul öncesi eğitimi öğretmenleri için hazırlanan kaynaştırma eğitimi programının neleri içermesi gerektiği konusunda öğretmenlerin görüşlerinin, bu araştırmanın en güçlü yönü olduğu düşünülmektedir. Öğretmenlerin teorik bilgiden çok, uygulamada kullanacakları müdahale yöntemlerine gereksinimleri olduğunu ve bu gereksinimleri karşılandığı zaman hizmet içi eğitim programlarının amacına ulaştığ1nı vurguladıkları görülmüştür. Uluslararası alan yazında son yıllarda yapılan çalışmaların, okul öncesi eğitimi öğretmenlerinin ve öğretmen adaylarının kaynaştırma sınıflarında müdahale programlarını uygulayabilmeleri konusuna odaklandığı ve araştırmanın katılımcılarının ihtiyaçlarının bu bulgular ile paralellik gösterdiği görülmektedir (Macy, Squiers ve Barton, 2009; Odom, 2000; Rheams ve Bain, 2005; ScottLittle, Kagan ve Frelow, 2003). Öğretmenlerin hizmet içi programının; süresinin azlığı ve uygunsuz bir zamanda olması (ramazan ayı), yurt dışındaki örnek uygulamaların ve bireyselleştirilmiş eğitim programlarının hazırlanmasına yönelik bilgilerin olmaması konularını zayıf yönleri olarak işaret ettikleri görülmektedir. Bu bulgulardan, hizmet içi eğitim faaliyetleri planlanırken, zamanlamanın önemli bir unsur olduğu ve öğretmenlerin İşbaşında Ĕ̆itim gibi farklı hizmet içi eğitim uygulamalarına gereksinim duydukları anlaşılmaktadır. Ayrıca, öğretmenlerin, 
kaynaştırma uygulamaları gereği sınıflarındaki değişen öğrenci profilinin onları araştırmaya yönlendirdiği, meslektaşlarının uygulamalarını ve hatta yurt dişındaki uygulamaları görmeyi istedikleri anlaşılmaktadır. Araştırmanın bu bulguları, kaynaştırma eğitimi uygulamalarını, aldıkları sınırlı eğitimlerle yürüten okul öncesi eğitimi öğretmenlerinin geri bildirimlere ihtiyaç duyduklarını göstermektedir. Öğretmenlerin kaynaştırma eğitimi uygulamalarında Scott-Little, Kagan ve Frelow'un (2003) araştırma bulguları ile benzer biçimde, erken öğrenme standartlarının neler olması gerektiğini öğrenmek istedikleri anlaşılmaktadır. $\mathrm{Bu}$ bağlamda, kaynaştırma eğitiminin genel eğitim öğretmenlerinin sorumluluğunda yürütüldüğü düşünüldüğünde, okul öncesi eğitim öğretmenleri ve diğer eğitimciler için, sosyal beceriler, problem davranışlar ve uyum becerileri destek müdahale programları ve iyi örneklerin yer aldığı görsel materyallerin hazırlanarak hizmet içi eğitim etkinliklerinde bunların kullanımına yer verilmesi gerektiği düşünülmektedir.

Öğretmenlerin kaynaştırma uygulamalarında yaşadıkları sorunların, kaynaştırma öğrencisinin sınıflarına yerleştirilmesinden geç haberdar olmaları, ailelerden ve okul yönetimlerinden destek görmedikleri, sınıf mevcutlarının kalabalık oluşu ve fiziksel koşulların uygun olmayışı boyutlarında yoğunlaştığı araştırmanın bulguları arasında yer almaktadır. Bu bulguların, MEB'in daha az personel ile daha çok çocuğun istihdam edilerek okul öncesi eğitimde okullaşma oranlarını arttırma girişimlerinden kaynaklandığı bilinmektedir. Bu uygulamanın sınıflardaki çocuk sayısını arttırırken, okul öncesi öğretmenlerinin, fiziksel mekân, materyal yetersizliği ve sınıf içi problem davranışlarla karşılaşma ve müdahale uygulamaları konusunda yetersiz donanımlarından dolayı çaresizlik yaşama ve eğitimin niteliğini olumsuz etkileyeceği de bilinmektedir (Altun ve Gülben, 2009; Gök ve Erbaş, 2011; Kaynaştırma Yoluyla Eğitim Uygulamaları, 2008; Temel, 2000) 
Okul öncesi öğretmenlerinin, kaynaştırma eğitiminde yaşanan sorunlara ilişkin çözüm önerilerine; genel müdürlüğe, okul yönetimine, ailelere, uzmanlara ve meslektaşlarına yönelik olarak araştırmanın bulguları arasında yer verişmiştir. Genel müdürlüğe yönelik önerilerinin; sınıf mevcutlarının yönetmeliğe uygun düzenlenmesi, kendilerine özel eğitim danışmanlı̆̆ı ve sınıflarına yardımcı öğretmen verilmesi, fiziksel ortamların ve araç-gereçlerin düzenlenmesi ve özellikle ilköğretim okul yöneticilerine de okul öncesi eğitimde kaynaştırma eğitimi konusunda seminerler verilmesi şeklinde yoğunlaştığ görülmektedir. Okul yönetimlerine yönelik önerilerini ise destek ve anlayış, materyal sağlama ve aile-okul işbirliğinde destek olmaları şeklinde ifade ettikleri görülmektedir. Ailelere yönelik önerilerinin ise; öncelikle çocuklarını kabullenmeleri, okulla iş birliği yapmaları ve çocuklarının eğitim gereksinimlerini araştırmaları yönünde yoğunlaştığı görülmektedir. Alandaki uzmanlara yönelik önerilerini ise; MEB ile daha fazla iş birliği yaparak benzeri seminerlerin her ilde daha çok yapılması, görsel materyaller ile uygulama örneklerine yer verilmesi, lisans eğitimleri sırasında öğretmen adaylarının özel eğitim ve kaynaştırma eğitimi konusunda teşvik edilmeleri gerektiği konularını sıraladıklar1 görülmektedir. Öğretmenlerin çözüm önerileri incelendiğinde, çoğunlukla kaynaştırma uygulamasından tek başlarına sorumlu oldukları ve kaynaştırma eğitiminde yer alması gereken diğer ekip üyelerinin duyarsız davrandıkları anlaşılmaktadır. Ülkemizde henüz okul öncesi eğitimde istenen nicel ve nitel hedeflere ulaşlamamış ve erken eğitimin öneminin geç fark edilmiş olmasının kaynaştırma eğitimi uygulamalarını ve ilgili aktörlerin tutumlarını da olumsuz etkilediğini düşündürmektedir. Öğretmenlerin çoğunluğunun kaynaştırma ve erken eğitimin önemli olduğunu kabul ettikleri ve başarılı olmak için bireysel çaba harcadıkları görülmektedir. Öğretmenlerin görüşlerinden, ilgili aktörlerin sosyal desteğinin çok daha önemli olduğunu vurguladıkları 
anlaşılmaktadır. Mevcut sistem içinde öğretmenlere ulaşan tek desteğin hizmet içi ve il boyutundaki eğitimlerin olduğu ve bu eğitimlerin niteliğinin öğretmenlerin yaşadıkları sorunlara yönelik olarak düzenlenmesinin başarılarını arttıracağına inandıkları, kaynaştırma öğrencilerinin gelişimlerinde ilerleme izledikleri zaman hoşnut oldukları ve kendilerine olan öz güvenlerinin arttığı anlaşılmaktadır. Ancak hizmet içi eğitimler programlarında söz konusu düzenlemeler yapılırken, okul öncesi öğretmenlerine özel eğitim danışmanlığı, sınıfta yardımcı bir öğretmen ve kaynak oda desteğinin ivedi olarak sunulmasının hem okul öncesi eğitimin hem de kaynaştırma eğitimi uygulamalarının başarısını artt1racağına inanılmakta ve eğitim sistemimize katkıları olacağı düşünülmektedir.

\section{Sonuç}

Sonuç olarak, bu araştırmanın katılımcıları olan okul öncesi eğitimi öğretmenlerinin çoğunlukla kaynaştırma eğitimi uygulamalarından kendilerinin sorumlu olduğu ve almış oldukları eğitimlerle mesleki yeterlilikleri doğrultusunda uygulamaları sürdürdükleri görülmüştür. Öğretmenlerin, Kaynaştırma Ĕ̆itimi Hizmet İçi Eğitim Programlarının, uygulamada yaşadıkları sorunlara yönelik olarak düzenlenmesinin yanı sıra özel eğitim danışmanlığı, sınıfta yardımcı bir öğretmen ve kaynak oda desteğine ihtiyaç duydukları sonucuna ulaşılmıştır.

\section{Uygulamaya Yönelik Öneriler}

- Özel eğitim gereksinimi olan çocuklarla çalışan okul öncesi öğretmenlerine öğretim yöntemleri, müdahale uygulamaları ve bunların nasıl uygulanacağ konusunda hizmet-içi eğitimlerle destek eğitim verilmelidir.

- Okul öncesi eğitimi öğretmenleri için hazırlanan Kaynaştırma Ĕ̆i- 
timi Hizmet-İçi Ĕgitim Programlarında iyi uygulama örneklerinin yer aldığı görsel materyallere yer verilmelidir.

- Hizmet içi eğitim modelleri, değişen öğrenci ve öğretmen ihtiyaçları doğrultusunda işbaşında eğitim, danışmanlık hizmeti, web destekli eğitim ve danışmanlık hizmeti gibi alternatif modellerle çeşitlendirilmelidir.

- Okul öncesi öğretmeni yetiştiren programlarda, öğretmen adaylarının kaynaştırma uygulamaları ve müdahale programları konulu derslerin zorunlu olması ve bu derslerin uygulamalı olarak yürütülmesi sağlanmalıdır.

- Yasal düzenlemelerde yer almasına rağmen, il boyutunda sınırlı uygulamaları olduğu bilinen, Gezici Özel Eğitim Öğretmeni kadrosu için teşvik edici çalışma şartları planlanarak uygulamanın aktif hâle getirilmesi sağlanmalıdır.

- Millî Eğitim Bakanlığı tarafından her bir eğitim kademesindeki (Okul öncesi, ilköğretim ve ortaöğretim) kaynaştırma eğitiminin durumuna ilişkin ulusal raporların hazırlanması gerekmektedir.

- Bağımsız okul öncesi eğitim kurumlarına (rehber öğretmen kadrosu yok) "Özel Eğitim Danışmanlığı” destek hizmeti sağlanmalıdır.

- Kaynaştırma uygulamalarında görev yapan okul öncesi öğretmenlerine, sınıf içinde yardımcı öğretmen desteği sağlanmalıdır.

- Okul öncesi eğitim sınıflarında özel gereksinimli çocukların ihtiyaçlarını karşılayacak ve öğretmenlerin sınıf yönetimine destek olacak, sosyal beceriler, problem davranışlar ve uyum becerileri destek müdahale programları geliştirilmelidir.

- Erken eğitim ve kaynaştırma eğitimi konularında toplumu bilinçlendirme programı geliştirilmelidir. 


\section{İleri Araştırmalara Yönelik Öneriler}

- Araştırmadan elde edilen bulguların genellenebilmesi amacıyla; aynı araştırma, farklı eğitim ortamlarında, farklı katılımcılarla ve farklı araştırmacılar tarafından yinelenebilir.

- Okul öncesi eğitimde kaynaştırma eğitimi uygulamalarında destek müdahale programları hazırlanarak öğretmenlerin uygulayabilme ve programların etkilik sonuçları değerlendirilebilir. 


\section{Kaynakça}

Altun, T. ve Gülben, A. (2009). Okul öncesinde özel gereksinim duyan çocukların eğitimindeki uygulamalar ve karşılaşılan sorunların öğretmen görüşleri açısından değerlendirilmesi [Çevrimiçi sürüm]. Ahmet Keleşoğlu Eğitim Fakültesi Dergisi, 28, 253-272.

Batu, E. S. ve Kırcaali-İftar, G. (2006). Kaynaştırma. Ankara: Kök Yayıncılık.

Brantlinger, E., Jimenez, R., Klingner, J., Pugach, M., ve Richardson, V. (2005). Qualitative studies in special education. Exceptional Children, 71, 195-207.

Baxter, P. ve Jack, S. (2008). Qualitative case study methodology: Study design and implementation for novice researchers. The Qualitative Report, 13(4), 544-559.

Gök, G. ve Erbaş, D. (2011). Okul öncesi eğitimi öğretmenlerinin kaynaştırma eğitimine ilişkin görüşleri ve önerileri. International Journal of Early Childhood Special Education, 3(1), 66-87.

Güven, Y. ve Önder, A. (1995). Okulöncesi eğitim kurumlarındaki yönetici ve öğretmenlerin özel eğitim gerektiren çocukların kaynaştırılmaları hakkındaki görüşleri. 11-13 Ekim Hacettepe Üniversitesi Çocuk Gelişimi ve Eğitimi Bölümü 2. Özel Eğitim Kongresinde sunulmuş bildiri. Ankara.

Kaynaştırma Yoluyla Eğitim Uygulamaları. (2008). Özel Eğitim Rehberlik ve Danışma Hizmetleri Genel Müdürlüğü. Genelge No:2008/60.

Kayılı, G., Koçyiğit, S., Doğru, S. S. Y. ve Çiftçi, S. (2010). Kaynaştırma eğitimi dersinin okul öncesi öğretmeni adaylarının kaynaştırmaya ilişkin görüşlerine etkisi. Mehmet Akif Ersoy Dergisi, 10(20), 48-65.

Macy, M., Squires, J. K. ve Barton, E. E. (2009). Providing optimal oppurtunities. Topics in Early Childhood Special Education, 28(4), 209-218.

Milli Eğitim Bakanlığı, 2010-2011 Eğitim İstatistikleri-Örgün Eğitim. Millî Eğitim Bakanlığı Strateji Geliştirme Başkanlığı.

Nonoyama-Tarumi, Y. ve Ota, Y. (2011). Early childhood development in developing countries: Pre-primary education, parenting, and health care. Education for All Global Monitoring Report. United Nations Educational, Scientific and Cultural Organization.

Odom, S., McConnell, S. ve Chandler, L. (1994). Acceptability and feasibility of class- 
room-based social interaction interventions for young children with disabilities. Exceptional Children, 60, 226-236.

Odom, S. L. (2000). Preschool inclusion: What we know and where we go from here. Topics in Early Childhood Special Education, 20, 20-27.

Okul Öncesi Eğitim Kurumları Yönetmeliği (2009). 31.07.2009 Tarih ve 27305 Sayılı Resmi Gazete

Özbaba, N. (2000). Okul öncesi ĕgitimcilerin ve ailelerin özel ĕgitime muhtaç çocuklar ile normal çocukların entegrasyonuna (kaynaştırılmasına) karşı tutumları. Yayımlanmamış yüksek lisans tezi, Marmara Üniversitesi, İstanbul.

Özel Eğitim Hakkında Kanun Hükmünde Kararname. 573 Sayılı. (1997). Milli Eğitim Basimevi. 230/11, 06.06. 1997

Özel Eğitim Hizmetleri Yönetmeliği (2006). 31.05.2006 Tarih ve 26184 Sayılı Resmi Gazete.

Rheams, T. A. ve Bain, S. K. (2005). Social interaction interventions in an inclusive era: Attitudes of teachers in early childhood self-contained and inclusive settings. Psychology in the Schools, 42, 53-63.

Scott-Little, C., Kagan, S. L. ve Frelow, V. S. (2003). Standards for preschool children's learning and development: Who has the standards, how were they developed, and how were they used? Greensboro, North Carolina: University of North Carolina, SERVE.

Seçer, Z., Çeliköz, N., Sarı, H., Çetin, Ş. ve Büyüktaşkapu, S. (2010). Okulöncesi Eğitim Kurumlarında çalışan Öğretmenlerin Kaynaştırma eğitimine yönelik tutumları (Konya ili örneği). Selçuk Üniversitesi Ahmet Keleşoğlu Eğitim Fakültesi Dergisi, 29, 393-406.

Sucuoğlu, B. ve Kargın, T. (2006). Illköğretimde kaynaştırma uygulamaları. İstanbul: Morpa Yayınları.

Sünbül, M. ve Sargın, N. (2002). Okul öncesi dönemde kaynaştırma eğitimine ilişkin öğretmen tutumlarının (çeşitli değişkenler açısından) incelenmesi. 12. Ulusal Özel Ĕ̆itim Kongresi bildiri içinde. (s.225-243). Ankara.

Şahbaz, Ü. ve Kalay, G. (2010). Okul öncesi eğitimi öğretmen adaylarının kaynaştırmaya ilişkin görüşlerinin belirlenmesi. Mehmet Akif Ersoy Üniversitesi Ë̆itim Fakültesi Dergisi, 10(19), 116-135. 
Temel, Z. F. (2000). Okul öncesi eğitimcilerinin engellilerin kaynaştırılmasına ilişkin görüşleri. Hacettepe Üniversitesi Eğitim Fakültesi Dergisi, 18, 148 -155.

Türkiye'de Kaynaştırma/Bütünleştirme yoluyla eğitimin durumu (2001). Kaynaştırma /bütünleştirmenin etkililiğini artırmak için politika ve uygulama önerileri projesi.

TÜSİAD (2005). Doğru Başlangıç: Türkiye’de Okul Öncesi Eğitim. Türk Sanayicileri ve İşadamları Derneği, TÜSİAD-T/2005-05/396.

Varlıer, G. ve Vuran, S. (2006). Okul öncesi eğitimi öğretmenlerinin kaynaştırmaya ilişkin görüşleri. Kuram ve Uygulamada Eğitim Bilimleri. Educational Sciences: Theory \& Practice, 6, 578-585.

Yıldırım, A. ve Şimşek, H. (2005). Sosyal bilimlerde nitel araştırma yöntemleri. Genişletilmiş 5. Baskı, Ankara: Seçkin Yayınevi. 


\section{Ek 1.}

\section{GÖRÜŞMECİ BİLGİ FORMU}

Kod adınız:

Görüşme tarihi:

Cinsiyetiniz:

Yaşınız:

Şu an çalıştığınız il:

Mezun olduğunuz üniversite/fakülte/program:

Mesleki deneyim yılınız:

Kaynaştırma deneyim yılınız:

Çalıştığınız kurum türü:

Görüşme Soru Formu

\begin{tabular}{|c|l|}
\hline 1- & $\begin{array}{l}\text { Okul Öncesi Eğitimi Genel Müdürlüğünce düzenlenen hizmet içi } \\
\text { eğitim seminerleri arasından “Okul Öncesi Eğitimde Kaynaştırma } \\
\text { Eğitimi” seminerini seçme nedeninizi açıklar mısınız? }\end{array}$ \\
\hline 2- & $\begin{array}{l}\text { Daha önce özel eğitim ve/veya kaynaştırma eğitimleri ile ilgili eği- } \\
\text { timler aldınız mı? }\end{array}$ \\
\hline 3- & $\begin{array}{l}\text { Hangi tür yetersizliği olan çocuklar ile çalışıorsunuz/çalıştınız? Açık- } \\
\text { lar mısınız? }\end{array}$ \\
\hline $4-$ & $\begin{array}{l}\text { Yetersizliği olan çocuklarla çalışırken yaşadığınız sorunlar nelerdir? } \\
\text { Açılar mısınız? }\end{array}$ \\
\hline 5- & $\begin{array}{l}\text { Bu sorunları çözerken neler yapıyorsunuz? Kimlere, hangi kurumlara } \\
\text { başvuruyorsunuz? Çabalarınız nasıl sonuçlanıyor? }\end{array}$ \\
\hline 6- & $\begin{array}{l}\text { "Okul Öncesi Eğitimde Kaynaştırma Eğitimi” seminerine gelmeden } \\
\text { önceki beklentileriniz nelerdi? Açıklar mısınız? }\end{array}$ \\
\hline 7- & $\begin{array}{l}\text { Size sunulan “Okul Öncesi Eğitimde Kaynaştırma Eğitimi” semineri } \\
\text { beklentilerinizi karşıladı mı? }\end{array}$ \\
\hline
\end{tabular}




\begin{tabular}{|l|l|}
\hline 8- & $\begin{array}{l}\text { "Okul Öncesi Eğitimde Kaynaştırma Eğitimi” semineri hizmet içi } \\
\text { eğitim programının sürecine ilişkin görüşleriniz nelerdir? } \\
\text { a) Konuların içeriği; } \\
\text { b) Uzmanların yeterlikleri; } \\
\text { c) Ders işleniş yöntemi; } \\
\text { d) Programın süresi; }\end{array}$ \\
\hline 9- & $\begin{array}{l}\text { “Okul Öncesi Eğitimde Kaynaştırma Eğitimi” seminerinde işlenen } \\
\text { konulara eklemek istediğiniz konular var mı? Varsa lütfen sıralayınız. }\end{array}$ \\
\hline 10- & $\begin{array}{l}\text { Size sorulacak olsa, sınıfınızda kaynaştırma öğrencisi ile çalışırken } \\
\text { ne tür destek eğitim hizmetleri almak istersiniz? Bu tür hizmetlere } \\
\text { gereksinim duyma nedenlerinizi açılar mısınız? }\end{array}$ \\
\hline 11- & $\begin{array}{l}\text { “Okul Öncesi Eğitimde Kaynaştırma Eğitimi” seminerinin sizce en } \\
\text { güçlü tarafları nelerdir? Açıllayınız? }\end{array}$ \\
\hline 12- & $\begin{array}{l}\text { "Okul Öncesi Eğitimde Kaynaştırma Eğitimi” seminerinin sizce en } \\
\text { zayıf tarafları nelerdir? Açıklayınız? }\end{array}$ \\
\hline $\begin{array}{l}\text { Okul öncesi eğitim kurumlarında kaynaştırma uygulamalarının ba- } \\
\text { şarılı olabilmesi için neler önerirsiniz? } \\
\text { a) Genel müdürlüğünüze; } \\
\text { b) Okul yönetiminize; } \\
\text { c) Ailelere; } \\
\text { d) Alan uzmanlarına; } \\
\text { e) Meslektaşlarınıza; }\end{array}$ \\
\hline
\end{tabular}

Okul öncesi eğitimi öğretmeni olarak, “Okul Öncesi Eğitimde Kaynaştırma Eğitimi”" hizmet içi eğitim seminer programına ve kaynaştırma uygulamalarına yönelik görüşlerimi ve deneyimlerimi hazırlanan sorular doğrultusunda içtenlik ve samimiyetle paylaşmayı kabul ettim. 